WADE, H. E. (1952). J. gen. Microbiol. 7, 24-30

\title{
Variation in the Phosphorus Content of Escherichia coli during Gultivation
}

\author{
BY H. E. WADE \\ Microbiological Research Department (Ministry of Supply), Porton, Wiltshire
}

\begin{abstract}
SUMMARY: Wide fluctuations of phosphorus concentration in the cells occur during the cultivation of Escherichia coli (Bacterium coli) on aerated media. The concentration of cell phosphorus increases rapidly during the stationary phase and early lag phase to a peak which coincides with the formation of half the first generation; it declines until the end of this generation and increases once again to a second peak, declining subsequently when growth and division rates fall off. Analyses of the cells during cultivation show that the different concentrations of ribonucleic acid largely account for these variations. The association of the initial phosphorus peak with the first generation has been observed during the cultivation of Esch. coli on several liquid media and on CCY medium at different temperatures. The increase in phosphorus concentration during the first generation can be associated quantitatively with the increase in average cell weight.
\end{abstract}

Variations in the phosphorus concentration of bacteria at different periods of growth were recorded by Leach (1906) and by Dawson (1919), but the bacteria used were for the most part derived from agar surfaces and were in consequence of ill-defined metabolic states. Later investigators used liquid cultures but usually confined their investigations to measurements of specific phosphate esters. The present investigation of changes in phosphorus concentration in cells during growth was intended to give not only an indication of gross changes that take place in the concentration of various phosphorus-containing constituents but also an indication of where more detailed analyses might most profitably be carried out.

\section{METHODS}

The organism used in these experiments was a strain of Escherichia coli (Bacterium coli), American type ' B'. The methods of cultivation used are given in Wade (1952). Cells used for inoculating experimental cultures were derived from a culture grown in the same medium and at the same temperature as the experimental culture, and harvested when the maximum concentration of cell material $/ \mathrm{ml}$. medium was just reached. These cells were washed once before use. This procedure almost abolished the growth lag, i.e. lag in the increase in cell mass, in all the cultures to be described.

Samples from experimental cultures were delivered into a sufficient volume of $36 \%(\mathrm{w} / \mathrm{v})$ formaldehyde to give a final concentration of $1 \%(\mathrm{w} / \mathrm{v}) \mathrm{HCHO}$. In addition to inhibiting further growth the formaldehyde retarded an apparent decrease in phosphorus concentration during subsequent washings, a decrease which was more severe in cells from young cultures than in those from mature cultures. Volumes of these samples sufficient to provide $15-30 \mathrm{mg}$. dry weight of cells were centrifuged down, taken up into formol saline, transferred to tared 
$8 \mathrm{ml}$. Pyrex test-tubes ( $7-8 \mathrm{~g}$.) and made up to $5 \mathrm{ml}$. with washings. The cells were centrifuged down in an angle centrifuge and washed finally in $5 \mathrm{ml} .0 .05 \%$ saline. The tubes were dried for 15-17 hr. at 100-105 ${ }^{\circ}$, cooled and weighed. The determinations were carried out in triplicate and gave a mean coefficient of variation of $\pm 0.49 \%$, i.e. $95 \%$ confidence interval of $\pm 2 \%$.

Incinerations for phosphorus determination were carried out in the same tubes, using sulphuric and nitric acids. Estimations were carried out according to the method of Fiske \& SubbaRow (1925), and are expressed as percentage cell dry weight. The mean coefficient of variation of these determinations was $\pm 0.54 \%$, i.e. $95 \%$ confidence interval of $\pm 2.3 \%$.

Loss of phosphate from the formaldehyde-treated cells in the time required to wash them prior to analysis was $c .1 .5 \%$ of the total phosphorus. The loss was similar in actively dividing cells and in 'resting' cells. In view of the small quantity involved no correction was made for this initial loss in the analyses described below.

Separation into various phosphate fractions was carried out by the methods of Schneider (1945). The cells were extracted with trichloroacetic acid and ethanol/ether mixture to remove acid-soluble phosphates and fat-soluble phosphate; nucleic acids were estimated by sugar estimations against yeast ribonucleic acid (RNA) and thymus deoxyribonucleic acid (DNA) standards. RNA was estimated by its colour formation with aniline (Tracey, 1950) and DNA by its colour formation with diphenylamine (Morse \& Carter, 1949). Estimation of the nucleic acids by their sugar reactions was used in preference to a phosphorus fractionation technique because of the small weight of material available from samples. In order to facilitate a direct comparison of the changes which occurred in individual phosphorus fractions it was desirable to express the nucleic acids in terms of phosphorus/cell dry weight in common with other phosphate fractions. To effect the conversion the following procedure was adopted. Cells from a mature culture were analysed by the Schmidt \& Thannhauser (1945) technique to determine the phosphorus associated with each nucleic acid; a determination was also made by the Schneider (1945) technique to determine the equivalent of yeast RNA and thymus DNA present. The ratios of these two determinations enabled results to be expressed as phosphorus concentration of cell material and made the determinations independent of nucleic acid standards. The closeness of the values of total phosphorus concentration of the dry cell material, as calculated by addition of individual phosphorus fractions to the directly determined values, justified conversion in this manner (Fig. 4).

Total cell counts were made with a Petroff-Hausser counter; the $95 \%$ confidence interval for these results was $\pm 6-8 \%$. Cell weight was calculated from dry-weight determinations and total cell counts.

\section{RESULTS}

Growth and \% total phosphorus/cell dry wt. (\% TP/dry wt.) were followed during culture in CCY medium (Gladstone \& Fildes, 1940), tryptic meat broth (TMB), and ammonium lactate medium at $37^{\circ}$ inoculated to an initial cell 
concentration of $5 \times 10^{8}-10^{9} \mathrm{cells} / \mathrm{ml}$. During growth on CCY (Fig. 1) the $\% \mathrm{TP} /$ dry wt. increased and remained high until the growth rate decreased. Similar but smaller variations were observed on ammonium lactate medium (Fig. 2), but on this medium the \% TP/dry wt. curve was complicated by an unexpected decrease, repeatedly obtained, at $c .100 \mathrm{~min}$.

Fig. 3 shows the variation of TP/dry wt. in two CCY cultures inoculated with $c .2 \times 10^{8}$ cells $/ \mathrm{ml}$. The phosphorus curve shows a marked decrease in $\%$ TP/dry wt., with the first maximum at the time of first division.

Fractionations into various phosphate fractions were carried out on samples taken from the culture described in Fig. 3, Exp. (a); the results of these fractionations are shown in Fig. 4.

On TMB and $2 \%$ peptone (two other media that supported rapid growth) decreases in size of inocula to $c .2 \times 10^{8}$ cells $/ \mathrm{ml}$. produced similar results. The initial \% TP/dry wt. peak found during growth on ammonium lactate could also be associated with the first generation, but the magnitude of the increase was much smaller.

There appeared at first sight to be a correlation between growth rate and the increase in $\%$ TP/dry wt. at the first generation. Fig. 5, which illustrates the results of several experiments using media that supported growth rates of $\mathbf{0} \cdot \mathbf{0 5 - 2 \cdot 7}$ doubling cell dry wt./hr., indicated a direct relationship.

The growth rate was now varied on CCY by varying the temperature; Fig. 6 shows the changes in $\%$ TP/dry wt. during growth at $23^{\circ}$. An initial peak associated with the first generation was observed, but the increase in $\% \mathrm{TP} /$ dry wt. remained the same as that observed on a CCY culture at $37^{\circ}$. Further experiments showed that on CCY the increase in $\% \mathrm{TP} /$ dry wt. remained the same over a range of temperatures $21-39 \cdot 5^{\circ}$ representing growth rates of $\mathbf{0} \cdot \mathbf{0 5}-\mathbf{2} \cdot \mathbf{0}$ doubling cell dry wt./hr. (Fig. 7).

That $\% \mathrm{TP} /$ dry wt. was more closely related to cell weight was suggested by the differences in duration of stationary phases observed in the cultures described (Figs. 5 and 7). A plot of the increase in average cell weight against the increase of $\% \mathrm{TP} / \mathrm{dry}$ wt. when half the first generation had been formed showed a direct relationship between the two and that the results illustrated in Figs. 5 and 7 could be accommodated on the one graph (Fig. 8).

\section{DISCUSSION}

There is considerable evidence in the literature that the RNA content of living cells is different at different times during growth; that the total phosphorus concentration should be affected is not therefore surprising. The results of phosphorus fractionations carried out on Esch. coli cells during growth (Fig. 4) have shown that changes in RNA content are in fact almost entirely responsible for the extensive changes in phosphorus concentration. The results described above may be compared with those of workers who have determined RNA throughout by the sugar reaction or who have determined the fluctuation of nucleotides in bacteria by ultra-violet absorption.

Caldwell, Mackor \& Hinshelwood (1950) obtained a correlation between RNA concentration in Bact. lactis aerogenes and the growth rate, when the 


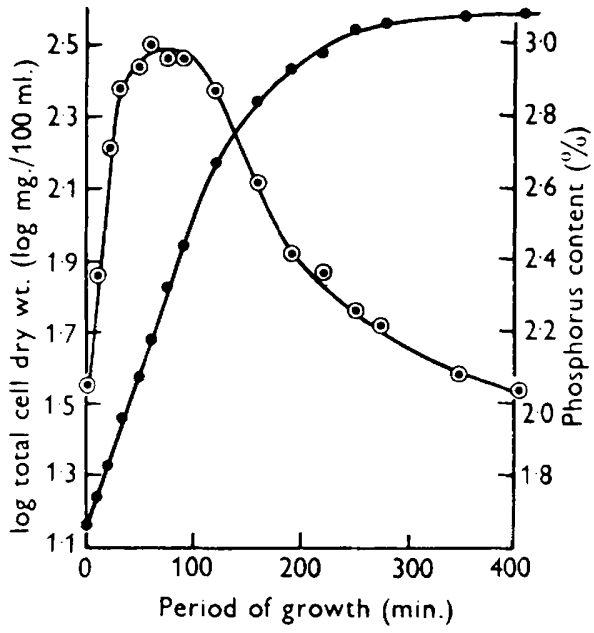

Fig. 1

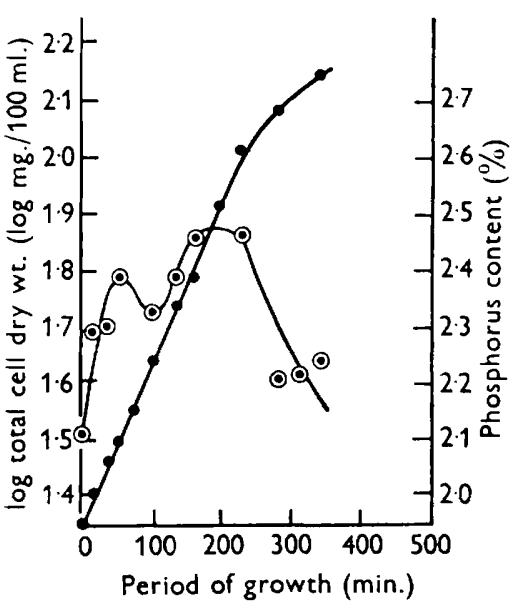

Fig. 2

Fig. 1. Variation of phosphorus content during growth on CCY at $37^{\circ}$. Log mg. dry wt. cells/100 ml. medium, - - -

Fig. 2. Variation of phosphorus content during growth on ammonium lactate medium at $37^{\circ}$. Log mg. dry wt. cells $/ 100$ ml. medium, - - ; total phosphorus \% cell dry wt., $-\odot-\odot-$.

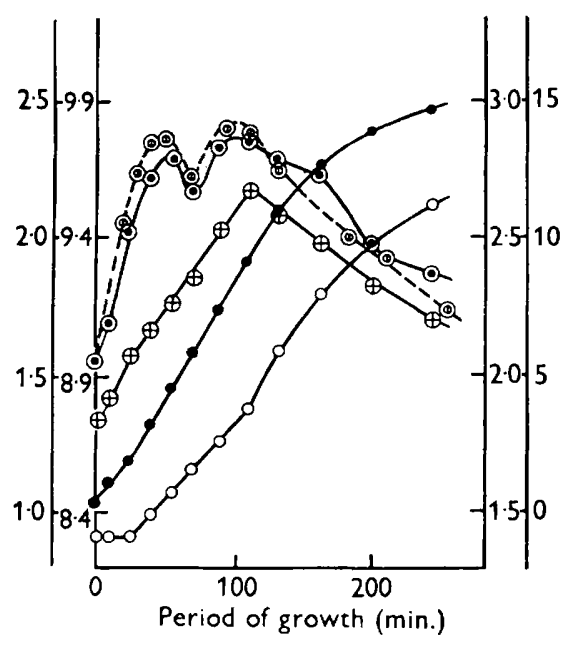

Fig. 3

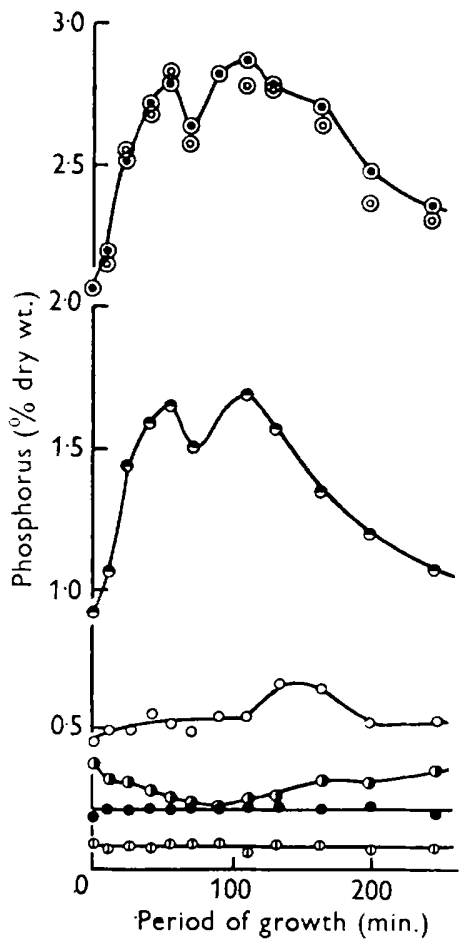

Fig. 4

Fig. 3. Variation of phosphorus content during growth on CCY at $37^{\circ}$; inoculum $c .2 \times 10^{8}$ cells/ml. Exp. (a) Ordinates : outer left, log mg. dry wt. cells/100 ml. medium, - $->$; inner left, log total cells/ml., - $\mathrm{O}-\mathrm{O}-$; outer right, average cell wt. $\left(\mathrm{mg} . \times 10^{-10}\right)$,

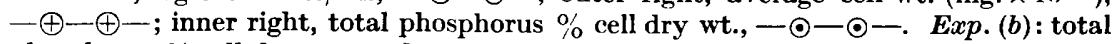
phosphorus \% cell dry wt., - (1)-(-)-

Fig. 4. Variation of phosphorus fractions during growth on CCY at $37^{\circ}$. Protein $P$, -(1)-D-; fat soluble $P$, $\longrightarrow-$; acid soluble $P,-O-O-$; DNA phosphorus, -O-O-; RNA phosphorus, - $-O-\Theta-$; calculated total P, - (-@-; determined total $P,-\odot-\odot-$. 

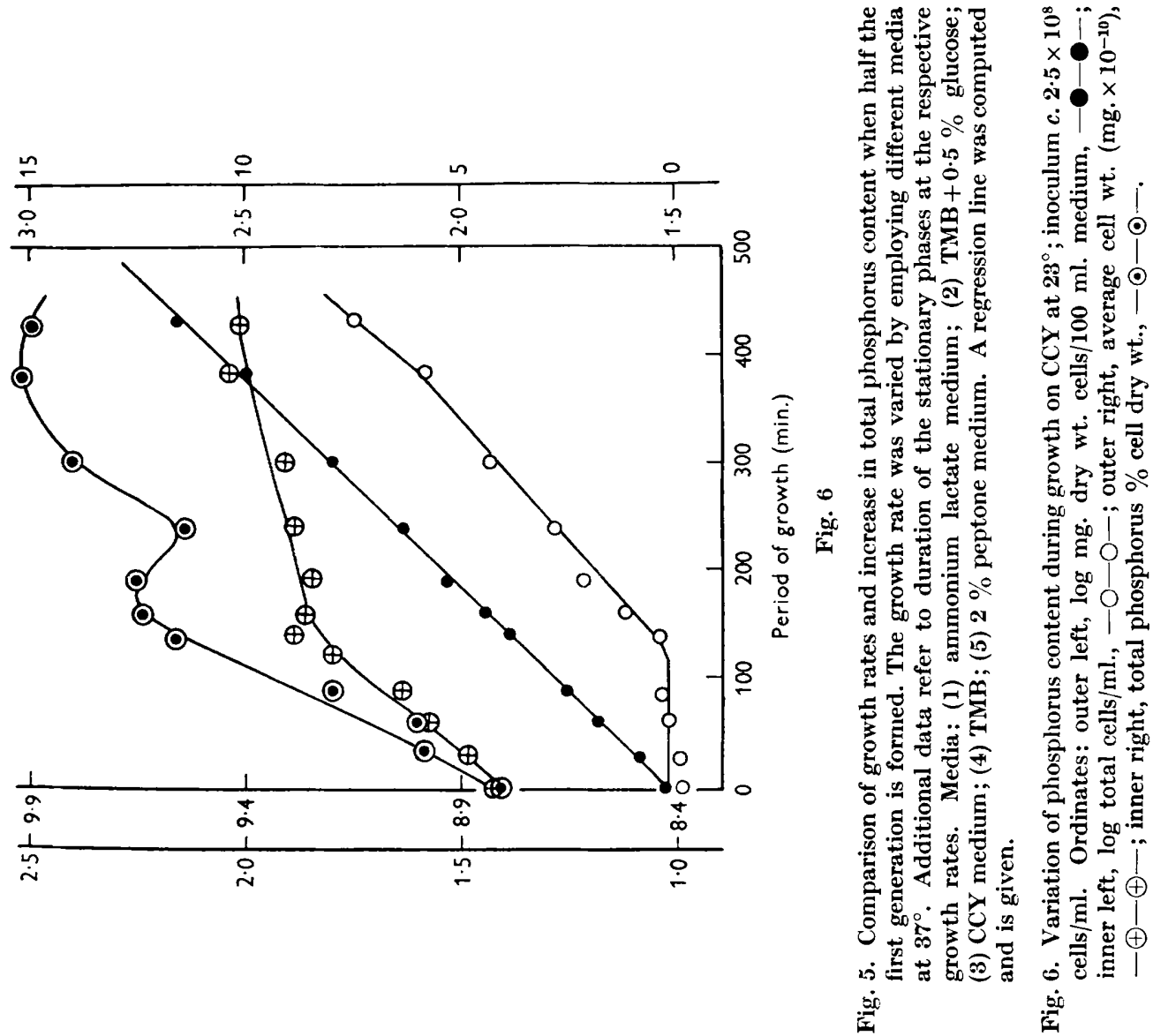

(uiu) วseyd

haruotaejs jo voljeana

요용

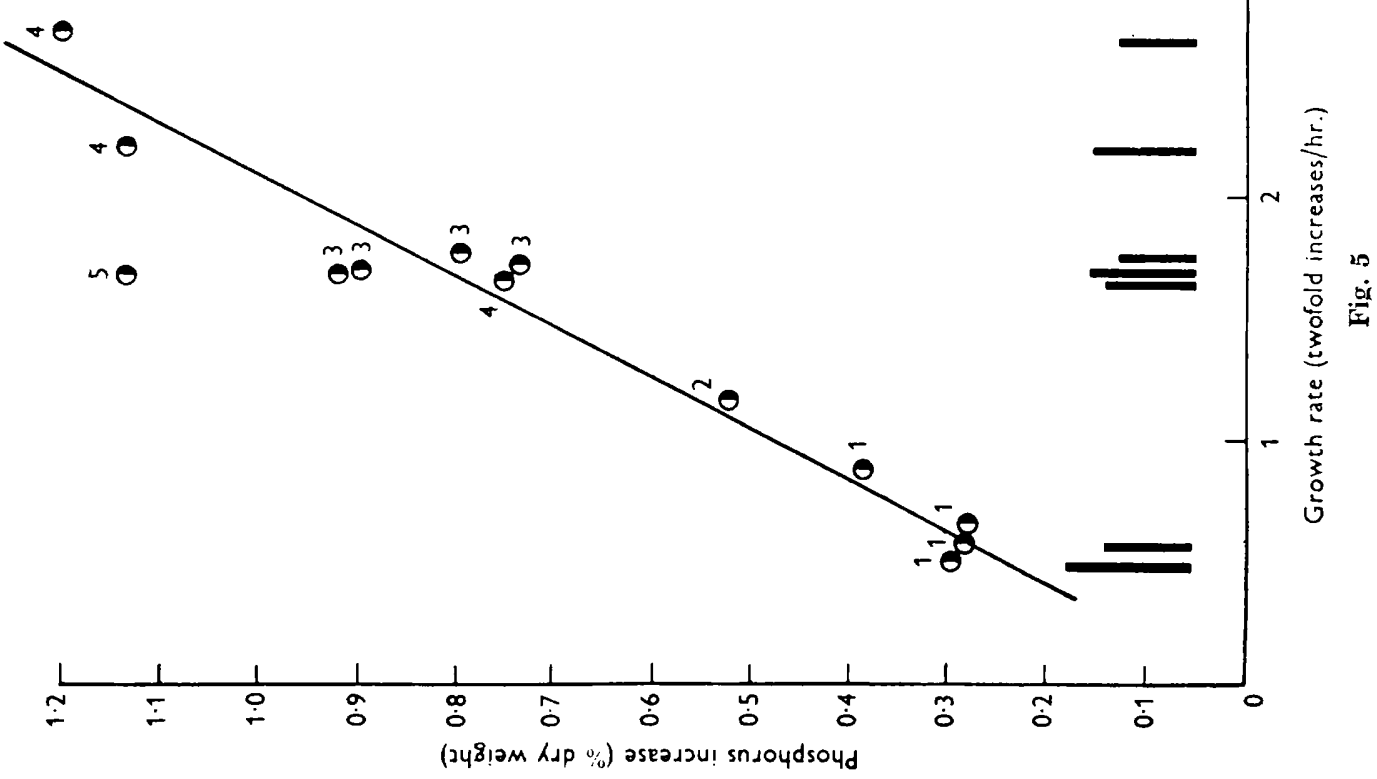


latter was varied by alterations to the medium. Fig. 5 representing this relationship for cells of the first generation confirms this for Esch. coli. However, the results of individual experiments have shown that at the time of inoculation the growth rate becomes maximum almost immediately, whereas

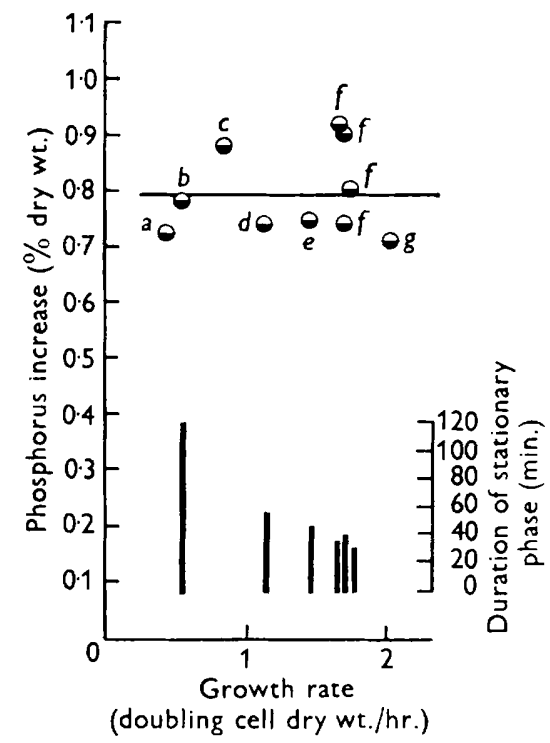

Fig. 7

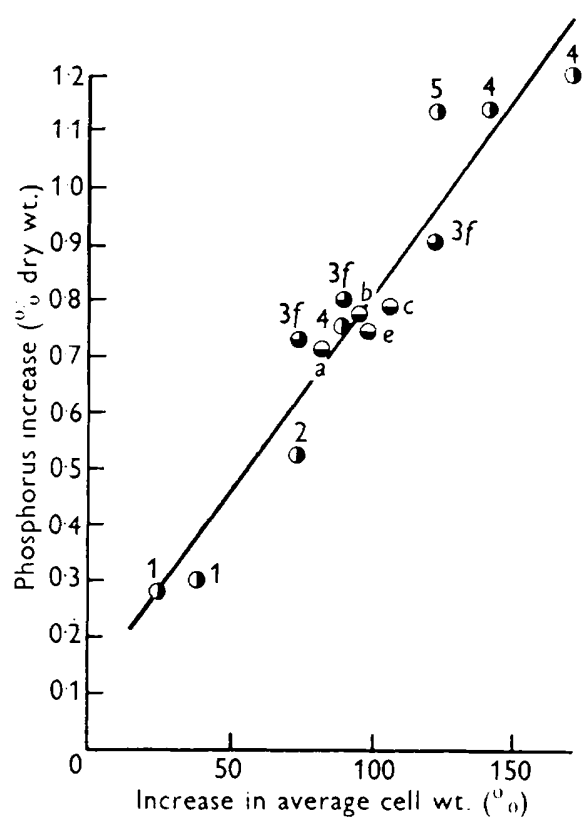

Fig. 8

Fig. 7. Comparison of growth rates and increase in total phosphorus content when half the first generation is formed during growth in CCY - the growth rate was varied by growing at different temperatures. Additional data refers to duration of the stationary phases at the respective growth rates. Temperatures: $(a) 21^{\circ} ;(b) 23^{\circ} ;(c) 25^{\circ} ;(d) 30^{\circ}$; (e) $35^{\circ} ;(f) 37^{\circ} ;(g) 39 \cdot 5^{\circ}$. A regression line was computed and is given.

Fig. 8. Comparison of increase in total phosphorus content and average cell weight when half the first generation is formed. The cultures had widely different growth rates, varied by employing different media at $37^{\circ}, \bigcirc$ (numbers refer to the media listed in fig. 5) and by varying the temperature of growth in CCY cultures $\ominus \bullet$ (letters refer to temperatures listed in Fig. 7). A regression line was computed and is given. It does not differ significantly from a line passing through the origin.

the increase in RNA takes at least until half the first generation to reach maximum - suggesting that the relationship is not a direct one. In addition, the evidence reported here suggests that the relationship does not hold when the growth rate is varied on the same medium by varying the temperature.

Working with Esch. coli and determining nucleic acid content from the ultra-violet absorption of the cells, Malmgren \& Hedén (1947) found a direct relationship between the generation time and the amount of nucleic acid formed (Morse \& Carter, 1949, later showed that RNA was mainly responsible). However, it did not hold true for the first generation. In the light of the evidence reported here this suggests that the bacterial cell requires a certain concentration of RNA, dependent upon its size, before it can divide. A plausible 
explanation of the temporary drop in RNA towards the end of the first generation (Figs. 4,5 ) is that in the course of the first division part of the RNA phosphorus is metabolized into other phosphates or is lost from the cell.

I am pleased to acknowledge the assistance of Sgt. D. M. Morgan. I wish to thank Dr D. W. Henderson for his encouragement and advice and Dr D. Herbert and Major L. H. Kent for helpful criticism of this paper. The statistical treatment of results was carried out under the guidance of Mr S. Peto.

\section{REFERENCES}

Caldwell, P. C., Mackor, E. L. \& Hinshelwood, C. (1950). The ribose nucleic acid content and cell growth of Bact. lactis aerogenes. J. chem. Soc. p. 3151.

Dawson, A. I. (1919). Bacterial variations induced by changes in the composition of culture media. J. Bact. 4, 133.

Fiske, C. H. \& SubbaRow, Y. (1925). The colorimetric determination of phosphorus. J. biol. Chem. 66, 375.

Gladstone, G. P. \& Fildes, P. (1940). A simple culture medium for general use without meat extract or peptone. Brit. J. exp. Path. 21, 161.

LEACH, M. F. (1906). On the chemistry of Bacillus coli communis. J. biol. Chem. $1,463$.

MALMgRen, B. \& HEdÉn, C. (1947). Studies of the nucleotide metabolism of bacteria. III. The nucleotide metabolism of the gram negative bacteria. Acta path. microbiol. scand. 24, 448.

Morse, M. L. \& Carter, C. E. (1949). The synthesis of nucleic acids in cultures of Escherichia coli, strains B and B/R. J. Bact. 58, 317.

Schmidt, G. \& Thannhauser, S. J. (1945). A method for the determination of desoxyribonucleic acid, ribonucleic acid and phospho-proteins in animal tissues. J. biol. Chem. 161, 83.

Schneider, W. C. (1945). Phosphorus compounds in animal tissues. I. Extraction and estimation of desoxypentose nucleic acid of pentose nucleic acid. J. biol. Chem. 161, 293.

Tracey, M. U. (1950). A colorimetric method for the determination of pentoses in the presence of hexoses and uronic acids. Biochem. J. 47, 433.

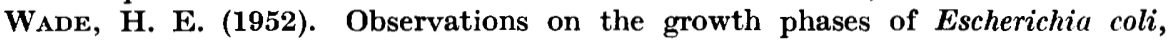
American Type 'B'. J. gen. Microbiol. 7, 18.

(Received 9 October 1951) 